\title{
The Results of 2019 Parliamentary Elections in the Perspective of 2018 Local Government Elections
}

\begin{abstract}
The analysis of the results of the elections to regional parliaments of 2018 allows to take a closer look at the current political preferences of the electorate one year before the parliamentary elections. The distribution of support for political parties in individual provinces shows that Law and Justice (PiS) enjoys constant, high and stable support, which will most likely allow this party to extend mandate to rule the country for the next 4 years. The largest opposition party, the Civic Platform (PO), sees the chances of victory in uniting further opposition groups around itself. The common start with Nowoczesna under the name of the Citizens' Coalition (KO) did not meet the expectations. However, the distribution of support in the local government elections showed that the actions consolidating the opposition are currently the only chance to fight a leveled electoral fight with Law and Justice (PiS).
\end{abstract}

Keywords: 2018 local government elections, 2019 parliamentary elections, Law and Justice, Citizens' Coalition, Civic Platform

\section{Introduction}

With the end of process of emergence of new authorities of individual provinces, the postelection image of Poland became complete. Alongside the official results of the elections, the distribution of seats in individual regional parliaments and finally shaped political alliances in each of them, it is tempting to assess the potential of individual electoral committees in the perspective of 2019 parliamentary elections. This assessment does not only result from the scale of received support in the national dimension. It is also influenced by other indicators, such as: the scale of mobilization of own electorate, changes in support tendencies in the longer term or coalition capability (Krawczyk, Sterczyński 2008; Nikolski 2011, p. 205-266; Jednaka, 1997; Marszałek-Kawa, 2007). Only their combined list allows to draw conclusions that can serve as a prognostic for the future. 
The paper analyzes the results of province assemblies elections. The purpose of this paper is to analyze the support distribution for individual each political formation at the local level and to find the differences in behavior of electorate across different provinces. Defining the nature of these differences and their persistence will allow the author to predict forecasts for the parliamentary elections in 2019.

\section{The Results of the Elections to Regional Parliaments}

Regional parliament elections have their own specificity, so it is important be careful with the simple translation of support for individual parties to their popularity on a national scale. Although domestic politics increasingly affects electoral decisions, local committees remain strong in some regions. Some citizens also adopt different decision-making criteria depending on the type of election (Matyja,2013,pp.273-386). However, it is noticeable that there are some permanent sociopolitical divisions across Poland, rooted in historical conditions. They influence voters' decisions regardless of the type of elections (The Economist, 2018).

Taking these objections into account, it is true that the elections to regional parliaments most closely resemble those of a central character (Nikolski, 2011,pp. 54-59). Considering only this criterion in the last elections, Law and Justice (PiS) won with the support at the level of approx. 34\%. The second place was taken by the Citizens' Coalition (KO) (common electoral list of the Civic Platform (PO) and Nowoczesna) with the result of almost $27 \%$. The following were in further positions: Polish Paesant Party (PSL) (12\%), the Democratic Left Alliance (SLD Lewica Razem) (over 6.5\%), Kukiz 15 (approx. 5.5\%) and Non-Partisan Local Authorities (slightly over 5\%) (PKW, 2018). The mentioned committees have exceeded the minimum $5 \%$ threshold in the parliamentary elections.

Situation changes when one considers the participation of the committees ruling in the individual regional parliaments (and yet obtaining and exercising power is one of the most important politics' objectives). In this perspective, the elections ended in a 'draw'. The Law and Justice, like Citizens' Coalition, will rule or co-rule in 8 provinces. However, if the change in this matter was considered in relation to the previous local elections, it would turn out that the Law and Justice, at the expense of the Civic Platform-Polish Peasant Party coalition, gained as many as seven provinces (Kulas, Wendt, 2018, pp. 63-70).

There are much more factors that would influence the assessment of the final result. One could compare in absolute terms the increase or decrease of the electorate of individual formations or follow the dynamics of changes at the level of municipalities and districts. This analysis will be based on the results for regional assemblies. However, the location of support in particular provinces is of more importance for it than its scale at the national level.

Although the Law and Justice and Citizens' Coalition equally shared provinces, a more in-depth look at the results in each of them makes it to assess this 'draw' differently. Law and Justice gained an independent majority in as many as six provinces (Podlasie, Subcarpatian, Lublin, Lesser Poland, Świętokrzyskie and Łódź) (PKW, 2018), in the Lower Silesian Province 
it entered into a coalition with Non-Partisan Local Authorities, while in Silesia the missing mandate, giving an independent majority, gained this party by concluding an agreement with one of the councilors of the Citizens' Coalition.

On the other hand, the Citizens' Coalition only in the Pomeranian Province gained enough seats to not need a coalition partner to exercise authority. In four provinces (Masovian, Warmian-Masurian, Kuyavian-Pomeranian and Greater Poland) it will co-govern with the Polish Peasant Party. In the next three regions, the winner, apart from the Polish Peasant Party, was forced to enter into a coalition with a third entity: in the Opolskie Province with the German Minority, in the Lubuskie and West Pomeranian with the Democratic Left Alliance (Radio Zet, 2018).

Apart from the specifics of the D'Hont method, which, when translating support into mandates, promotes stronger parties, the differentiation of the electorate structure at the provinces level is clearly visible. In Eastern regions that traditionally sympathize with Law and Justice, the concentration of voters around its lists is much higher than analogous accumulation of voters of the Citizens' Coalition in provinces, which usually supported the Civic Platform.

\section{Eastern Poland, Central and 'Western Strip'}

In principle, Poland, on the basis of local elections' results, can be divided into three parts: Eastern (with a clear Law and Justice domination), Central (with stable, though weakening, support for the coalition of Civic Platform and Polish Peasant Party) and 'western strip', of which characteristic feature is large dispersion of the electorate (Nikolski, 2011, pp. 102-149; Kulas, Wendt, 2018, pp. 108-125). The presented division does not fit into three regions. In the local elections, the Opolskie Province has its own specificity, due to the strong position of the German Minority (Kowalczyk, Sterczyński, 2008). However, the final distribution of seats in Mazovia was influenced by the presidential campaign in Warsaw, and in the Silesian Province by behind-the-scenes negotiations. These two cases call for a separate analysis, which will be taken later in the text.

\begin{tabular}{lccccccc}
\hline Province & PiS & KO & PSL & SLD & Kukiz 15 & $\begin{array}{l}\text { Non-Parti- } \\
\text { san Local } \\
\text { Authorities }\end{array}$ & $\begin{array}{l}\text { Local } \\
\text { Com- } \\
\text { mittee }\end{array}$ \\
\hline \multicolumn{7}{c}{} & \multicolumn{7}{c}{ Eastern Poland } \\
\hline Lublin & 44,04 & 18,19 & 19,30 & 5,89 & 6,64 & - & - \\
\hline Łódź & 34,88 & 28,39 & 13,06 & 6,32 & 5,86 & - & - \\
\hline Lesser Poland & 43,55 & 22,66 & 10,03 & - & 5,76 & - & - \\
\hline Subcarpathian & 52,25 & 13,44 & 11,88 & 5,85 & 6,62 & - & - \\
\hline Podlaskie & 41,64 & 24,14 & 15,66 & - & 5,90 & - & - \\
\hline Śiętokrzyskie & 38,40 & 11,79 & 25,52 & 6,16 & - & - & 5,26 \\
\hline
\end{tabular}




\begin{tabular}{|c|c|c|c|c|c|c|c|}
\hline Province & PiS & KO & PSL & SLD & Kukiz 15 & $\begin{array}{l}\text { Non-Parti- } \\
\text { san Local } \\
\text { Authorities }\end{array}$ & $\begin{array}{l}\text { Local } \\
\text { Com- } \\
\text { mittee }\end{array}$ \\
\hline \multicolumn{8}{|l|}{ Central Poland } \\
\hline $\begin{array}{l}\text { Kuyavian- } \\
\text { Pomeranian }\end{array}$ & 28,27 & 34,66 & 14,31 & 9,00 & 5,70 & - & - \\
\hline Pomeranian & 27,84 & 40,70 & 8,33 & 6,59 & 5,24 & - & - \\
\hline $\begin{array}{l}\text { Warmian- } \\
\text { Masurian }\end{array}$ & 28,15 & 30,40 & 19,64 & 8,16 & 6,29 & - & - \\
\hline Greater Poland & 27,84 & 29,66 & 14,52 & 9,31 & 5,23 & 6,08 & - \\
\hline \multicolumn{8}{|c|}{,Western strip' } \\
\hline Lower Silesian & 28,53 & 25,77 & 5,23 & 5,50 & - & 14,98 & 8,29 \\
\hline Lubuskie & 25,11 & 29,92 & 12,43 & 9,59 & - & 13,17 & - \\
\hline West-Pomeranian & 26,80 & 32,04 & 9,68 & 9,08 & - & 13,70 & - \\
\hline \multicolumn{8}{|c|}{ Others } \\
\hline Masovian & 34,04 & 27,66 & 13,15 & 5,46 & 5,44 & 6,24 & - \\
\hline Opolskie & 25,77 & 29,45 & 10,72 & 5,94 & 6,06 & - & 14,64 \\
\hline Silesia & 32,11 & 28,83 & 5,15 & 8,31 & 6,58 & - & - \\
\hline
\end{tabular}

Voting results in percent (results above $5 \%$ included). Based on National Electoral Commission (PKW) data.

At this point, it is worth to take closer look at the specifics of the awarded 'western strip', which consists of three provinces: West Pomerania, Lubusz and Lower Silesian. They were separated on the basis of one common denominator. In each of these regions, the list of Non-Partisan Local Authorities received more than 10\% support (PKW, 2018). Thus, questions naturally arise about the reasons for this support.

It is the result of a process that was first noted in 2014. At that time, local committees successfully debuted in the Lubuskie and West-Pomerania Provinces (Jacuński, 2017; Tomczak, 2017). Their good electoral result can be attributed to the weakening position of the Civic Platform, which, compared to 2010, lost about 9 percentage points in both provinces (Kulas, Wendt, 2018, p. 84-85). In 2018, there was a consolidation of non-partisan committees under the same name. The decision to unite forces proved to be right, because in the Lubusz and West-Pomerania Provinces Independent Peasants improved the results of local committees.

The Lower Silesian Province has a slightly different specificity. In Lower Silesia, already in 2010, there was a strong local committee whose leader was Rafał Dudkiewicz. The Civic Platform achieved a better result in 2014 than it had been four years earlier, only because the then city president did not repeat the maneuver like that from previous elections. At that time, also the Independent-Representatives had their first success in Lower Silesia (Żukiewicz, 2017). In 2018, Rafał Dudkiewicz once again showed his own committee 'With Dudkiewicz for Lower Silesia.'By this it is also possible to explain the failure of the Citizens' Coalition in the region, because he undoubtedly took away some of their support, making 
it impossible for the Coalition to win. However, he did not harm the Non-Partisan Local Authorities who improved their result (PKW, 2018).

The fact that common lists of Citizens' Coalition (KO) in the 'western strip' did not achieve the expected success can be interpreted as referring to the electoral success of Non-Partisan Local Authorities. At the beginning, it is enough to compare support obtained by the Citizens Coalition in the western regions with the results of Law and Justice (PiS) in the eastern provinces. The difference in concentration between the two electoral lists is clear. Law and Justice exceeded $40 \%$ support in Lesser Poland, Lublin and Podlaskie Provinces, and in Subcarpathian Province it gained over 50\% of support. In the 'western strip', the Citizens' Coalition managed to exceed 30\% only in West Pomeranian Province (PKW, 2018).

However, the right difference is revealed only when the results of both these committees are compared with the results obtained by them in the 2015 elections. This comparison has its significant limitations, but allows one basic conclusion to be formulated. Both Law and Justice and Citizens' Coalition received lower support in the mentioned provinces than in the parliamentary elections. This is a completely understandable fact, considering the specificity of local government elections. Nevertheless, there is a clear difference in the scale of the discussed decline. Law and Justice achieved worse result, on average, by 3.5 percentage points (for Subcarpathian, Lesser Poland, Lublin and Podlaskie Provinces), while the result of the Citizens' Coalition was lower than the total support of the Civic Platform and Nowoczesna from the 2015 elections by about 10 percentage points in each of the three western provinces (PKW, 2015; PKW, 2018).

The list clearly shows that common lists of two opposition parties did not bring the expected result, which would be the mobilization of the opposition electorate around them. In the "western strip", comparing to the 2014 local elections, the reached coalition allowed only a slight improvement in the election result of the Civic Platform in West Pomeranian and Lubuskie Provinces. The leaders of the opposition did not set such a goal.

Thus, the record-breaking electoral turnout (PKW, 2018) (also in Western Provinces) did not result in significantly higher support for the Citizens' Coalition in the 'western belt.'The results between the Citizens' Coalition and the Law and Justice were much more flattened than in the East. It can also be presumed that the higher mobilization of the electorate in the East served the Law and Justice, while in the West it did not hurt this Party, although this area is not friendly for this formation.

It seems that significant support for Non-Partisan Local Governments is connected in some part with the lack of political alternative for a large part of the inhabitants of western provinces. The outflow of the Civic Platform electorate following the parliamentary elections of 2011 was only halted, and the coalition with Nowoczesna did not reverse this trend. Non-Partisan Local Governmentists play a similar role to voters as Kukiz 15, at least when it comes to rejection of two parties dominating the political scene. The arguments against Law and Justice, having been formulated for three years, also do not convince those voters. 
Of course, it is difficult to predict how this large group will support the Non-Partisan Local Government in the next year. However, as in the East, it is hard to imagine that the Law and Justice electorate would be distracted (in none of the provinces where the PiS exceeded 40\% - Non-Partisan Local Governmentists did not exceed 4\%). Similarly, it is hard to expect that the list of opposition in the West will have much more support. The premise for such conclusions is the very high rate of voters mobilization, which in the East did not destroy the PiS position (it rather stabilized it), and in the West did not add too many bonus points for the KO.

At this point, it is worth to briefly mention about big cities, because in them the effect, which was more widely expected from common lists of the Citizens' Coalition, worked properly (Polityka w Sieci, 2018). In city agglomerations, high turnout was associated with mobilization of the 'anti-PiS' electorate around the main opposition committee. Probably, the reason for such a state was rather a wrong strategy of the ruling party. Nevertheless, failure in big cities was rather prestigious and psychological. And the result was primarily assessed by the result of the fight for Warsaw's Presidential seat. If the second round of elections in the capital came to an end, the scale of failure would not be considered so severe.

Law and Justice did not lose support in large urban centers, but the 'anti-PiS' electorate concentrated in the overwhelming majority around the Citizens' Coalition, although this fact was not necessarily due to the real affiliations of political voters. In the absence of the possibility to increase their support among residents of large cities, the only solution for Law and Justice is to silence the hot spots that are sensitive for this segment of voters, so that they are willing to spread their support among various entities. Besides, the concentration of the metropolitan electorate around the Citizens' Coalition also does not serve other opposition parties that would like to seek their support there (e.g. the potential party of Robert Biedroń.

\section{The United Opposition - Perspectives}

Returning to the main topic of consideration, it is necessary to look at the following provinces: Masovia and Silesian. After the official election results were announced, these regions were at the center of particular interest. The majority that emerged in them, opposing the ruling party, had only one mandate, which allowed them to take power. In the end, Law and Justice managed to break down the coalition in Silesia, and in Masovia it managed to defend itself. Apart from the ethical issue of the matter - how soon, just after the election, the will of voters can be changed through behind-the-scenes negotiations - it is worth looking at the issue from the perspective of effectiveness of the multi-stakeholder alliance against the Law and Justice. The more formation forms a part of such a block, the more vulnerable it is to the lack of consistency. Law and Justice also has a delicate advantage in Łódź (17 councilors out of 33) and Świętokrzyskie Provinces (16 councilors out of 30), but there the risk of changing power is lower. It is simpler to maintain unity in a coherent and uniform 
formation than to reconcile all the interests of different groups, whose only willingness is to dislike the ruling party. Conflict of interests and ideological differences can quickly lead to the decomposition of the entire system, and even if it does not happen, it's single members will be more likely to leave such a project tempted by political opponents, for whom a single voice means the prospect of taking full power. However, such a persuasive force does not have a multi-stakeholder platform that has to reconcile the expectations of a wide group of people (Cichosz, 2017, pp. 368-372). Thus, the Silesian casus is an important lesson for a possible broad 'anti-PiS' coalition.

Nevertheless, the Citizens' Coalition, as shown by the results of the local government elections, in its current form will not be able to effectively oppose Law and Justice (PiS). No wonder that there are still voices calling for its enlargement. Today, first of all, the Polish Peasant Party and the Democratic Left Alliance must answer the question whether or not to become a part of it.

The Polish Peasant Party suffered a definite defeat in the election. Rafał Trzaskowski saved them from the total defeat, whose support also affected voting for the province parliament in Warsaw itself. Thanks to this, the Citizens' Coalition obtained an additional mandate enabling it to form a coalition with the Polish Peasant Party. This allowed members of the PSL to keep in the tides in the largest Province and the ability to fill a large number of positions. The politician of this party, Adam Struzik, once again became the Marshal of Mazovia.

The Law and Justice strategy of the election campaign, consistently directed against the PSL, proved to be a success. The Polish Peasant Party lost its influence in the whole Eastern Poland, in which it had the strongest position (Alberski, Cichosz, 2017). If the results from exit polls were the right ones, the Party could still be a partner with the Citizens' Coalition, but the final results completely changed the situation. As of today, it seems probable that a strategic agreement will be reached between the Citizens' Coalition and the Polish Peasant Party regarding the upcoming European and parliamentary elections. Its' principles are not yet decided, but in the long-term they may contribute to the decline in the listings of the members of the Polish Peasant Party, who in the last parliamentary elections barely crossed the electoral threshold. Decision concerning an independent start carries the risk that the Party will not get into the Parliament, while its permanent alliance with the Citizens' Coalition may result in losing independence and also may result in a decline in support. The Polish Peasant Party gained mainly from the fact that this Party was able to distance itself from all political parties (even being in coalition with the Civic Platform), leave the possibility of agreement with various formations and act as an arbitrator on the Polish political scene. Agreement with the Citizens' Coalition rules out all the mentioned advantages.

The situation of the Democratic Left Alliance is slightly different. It was wrongly believed that the defeat in the 2015 elections permanently deletes the Alliance from Polish politics. The Party maintains stable support, which in the case of an independent start in the elections (and not in the coalition formula, as it was in 2015) allows it to be in the Parliament. Over 6\% support of local government formation (in the elections), which has not been participating in 
the political mainstream for three years, should be considered a moderate success. Although the Democratic Left Alliance lost some councilors in comparison to the elections from 4 years ago, the distribution of votes in the Lubusz and West Pomerania Provinces caused that it became an essential element in the coalition puzzle. The strength of the Democratic Left Alliance is not only strong criticism of Law and Justice (PiS), but also distancing itself from some of the Civic Platform (PO) proposals (Such a tactic seems to be promoted by the current SLD leader Włodzimierz Czarzasty). That is why the Alliance's entry into the Civic Coalition does not serve the interest of this Party, especially since it has real chances of crossing the electoral threshold alone. It also has peripheral structures and State budget financing, which are of significant importance for conducting the election campaign.

\section{Conclusions}

The analysis allows to formulate the following conclusions

Firstly, the Law and Justice was successful in local government elections. To the full victory (understood as the real goals that the party could form before the election), Law and Justice ran out of power in the Mazovian Province and the entry of its candidate for the second round of the presidential election in Warsaw. A potential threat in the perspective of the 2019 elections is the mobilization of the metropolitan electorate around the Citizens' Coalition.

Secondly, the Citizens' Coalition in the formula of the local government elections did not fulfill the hopes placed in it. It only slightly widened the traditional electorate of the Civic Platform.

Thirdly, for the Polish Peasant Party the next parliamentary elections will be a struggle to stay on the Polish political scene. The Democratic Left Alliance has a good chance of returning to the Parliament, but for Citizens' Coalition it should remain an independent partner.

Fourth, basing solely only on the results of the local 2018 elections, the electoral victory of Law and Justice in the upcoming parliamentary elections is almost certain. The mobilization of the electorate of this Party in the Eastern Provinces, with the lower concentration of opposition voters in the 'western strip' around the Citizens' Coalition, indicates the privileged position of the Law and Justice. In addition, some of the former Civic Platform voters are not willing to return to this formation, rather choosing "the third force".

Fifth, the chances of power being taken over by the united opposition forces should be regarded as insignificant, and consequently, the Law and Justice will probably held the office in government even if it does not obtain an independent majority again. The results of the local government elections indicate that the electoral bloc against the Law and Justice is not able to obtain the majority of seats in the Parliament. Nowadays, in Polish society there is a demand for a 'third power' (though not at the level that would allow electoral victory). Because it is mainly supported by the anti-system electorate or the one that challenges the 
eight-year-rule of the Civic Platform, such an entity (as Kukiz 15 formation is to this day's) will not be willing to enter into agreement with the 'third power.'However, depending on the scale of the victory of the Law and Justice (PiS), such a group may act as a formal coalition or become a back-up for the winning party, as some deputies may decide to move to the Law and Justice.

\section{References}

Alberski, R., Cichosz, M. (2017). Gra o regiony 2014: Wybory do sejmików województw. Wrocław: Institute of Political Science, University of Wrocław.

Cichosz, M. (2017). Gdzie czterech się bije, tam piąty (trochę) korzysta: Podsumowanie rywalizacji w wyborach do sejmików województw w 2014 r. In R. Alberski, M. Cichosz M. (Eds.), Gra o regiony 2014: Wybory do sejmików województw (pp. 355-373). Wrocław: Institute of Political Science, University of Wrocław.

Jacuński, M. (2017). Samorządowcy i obywatele kontra partyjni wyjadacze - walka Dawida z Goliatem: Wybory do sejmiku województwa lubuskiego. In R. Alberski, M. Cichosz M. (Eds.), Gra o regiony 2014: Wybory do sejmików województw (pp. 79-94). Wrocław: Institute of Political Science, University of Wrocław.

Jednaka, W. (1997). Zachowania wyborcze. In A. Antoszewski, R. Herbut (Eds.), Demokracje zachodnioeuropejskie: Analiza porównawcza (pp. 249-275). Wrocław: University of Wrocław.

Krawczyk, K., Sterczyński, K. (2008). Konsekwencje polityczne absencji wyborczej w wyborach do sejmików województw w 2006 roku. In J. Raciborski (Ed.), Studia nad wyborami: Polska 2005-2006 (pp. 122-133). Warsaw: Wydawnictwo Naukowe Scholar.

Krawczyk, K., Sterczyński, K. (2008). Zachowania wyborcze mniejszości niemieckiej na Ślasku Opolskim. In J. Raciborski (Ed.), Studia nad wyborami: Polska 2005-2006 (pp. 134-140). Warsaw: Wydawnictwo Naukowe Scholar.

Kulas, B., Wendt, J.A. (2018). Wybory samorządowe do sejmików wojewódzkich w Polsce: Analiza wyników i preferencji elektoratu, regiony stabilne i labilne w latach 2002-2014. Pelplin: Bernardinum.

Marszałek-Kawa, J. (2007). Wybory samorzadowe 2006 a kwestia nowelizacji samorządowej ordynacji wyborczej. In Samorząd terytorialny. Studium politologiczne, J. Marszałek-Kawa (ed.), Toruń: Dom Wydawniczy Duet, pp. 199-215.

Matyja, R. (2013). Rywalizacja polityczna w Polsce. Kraków-Rzeszów: Ośrodek Myśli Politycznej.

Nikolski, L. (2011). Partie polityczne w wyborach do sejmików województw 1998-2006. Toruń: Adam Marszałek Publishing House.

PKW. (2015). Wyniki XLS - wybory do Sejmu RP. Retrieved from: https://parlament2015.pkw.gov. pl/355_Wyniki_Sejm_XLS.

PKW. (2018). Dane w arkuszach. Retrieved from: https://wybory2018.pkw.gov.pl/pl/dane-w-arkuszach.

Polityka w Sieci. (2018). ANALIZA: 3 powody, które sprawiły, że duże i średnie miasta głosowały przeciw \#PiS. Retrieved from: https://politykawsieci.pl/analiza-3-powody-ktore-sprawily-ze-duze-i-sredniemiasta-glosowaly-przeciw-pis/?fbclid=IwAR2lpkm7twmy4-3ofwLjrGv-btrlsCVuqBfPTjHyPEtneLgPo4rJ6kC7r_Q.

Tomczak, Ł. (2017). Bez zmian z mocniejszym odcieniem zieleni: Wybory do sejmiku województwa zachodniopomorskiego. In R. Alberski, M. Cichosz M. (Eds.), Gra o regiony 2014: Wybory do sejmików województw (pp. 299-314). Wrocław: Institute of Political Science, University of Wrocław. 
The Economist. (2018.11.21). Imperial borders still shape politics in Poland and Romania. Retrieved from: https://www.economist.com/graphic-detail/2018/11/21/imperial-borders-still-shape-politics-inpoland-and-romania.

Żukiewicz, P. (2017). Gdy muzyka w polityka zmienia wolta pragmatyka, czyli jak Dudkiewicz (mimochodem) wsparł Kukiza: Wybory do sejmiku województwa dolnoślaskiego. In R. Alberski, M. Cichosz (Eds.), Gra o regiony 2014: Wybory do sejmików województw (pp. 27-40). Wrocław: Institute of Political Science, University of Wrocław.

\section{Author}

\section{Szymon Gajewski}

PhD, Contact details: sz.gajewski88@gmail.com 